\section{Building a food-resilient city through urban agriculture: The case of Ilorin, Nigeria}

\section{Akeem Ola}

\author{
DOI: http://dx.doi.org/10.18820/2415-0495/trp77i1.7 \\ Peer reviewed and revised October 2020 \\ Published December 2020 \\ *The authors declared no conflict of interest for this title or article
}

\begin{abstract}
The rise in urban population, accompanied by growing poverty and hunger, has triggered debates on the relevance of urban agriculture in addressing the challenges of food insecurity in urban centres. This article examines the effects of urban planning practice on urban agriculture (UA) in Ilorin, Nigeria, and how it has contributed to improving the resilience of the city to food shock. Adopting a cross-sectional survey design, primary and secondary data were used. A structured questionnaire was used to obtain primary data from randomly selected urban farmers. Secondary data were obtained from the publications of the Central Bank of Nigeria, the National Bureau of Statistics, and the Food and Agricultural Organization. Data collected were analysed using descriptive statistical techniques. Respondents' Agreement Index (RAI) was used to measure the variables influencing the performance of UA. Findings revealed that UA contributed $16.9 \%$ to meat/fish/egg requirements in the city; $4.5 \%$ to yam/cassava/potato requirements; $0.58 \%$ to vegetable requirements; $0.6 \%$ to fruit requirements, and $0.5 \%$ to grain requirements. RAI results indicated poor access to finance (0.93), limited land area (0.75), and lack of tenure security $(0.44)$ as the dominant variables influencing the poor contribution of UA to food security. It is recommended that UA be integrated into urban planning and that more land for farming be provided.
\end{abstract}

Keywords: Nutritional requirement, urban agriculture, urban planning, city resilience, food security

\section{DIE BOU VAN 'N VOEDSELBESTANDE STAD DEUR STEDELIKE LANDBOU: DIE GEVAL VAN ILORIN, NIGERIË}

Toenemende stedelike bevolking, tesame met groeiende armoede en honger, het debatte veroorsaak oor die belangrikheid van stedelike landbou om die uitdagings van voedselonsekerheid in stedelike sentrums aan te spreek. Hierdie artikel ondersoek die gevolge van stedelike beplanningspraktyk op stedelike landbou (UA) in Ilorin, Nigerië, en hoe dit daartoe bygedra het om die stad se veerkragtigheid vir voedselskok te verbeter. Die gebruik van 'n deursnee-opname-ontwerp is gebruik van primêre en sekondêre data. 'n Gestruktureerde vraelys is gebruik om primêre data van willekeurig geselekteerde stedelike boere te verkry. Sekondêre gegewens is verkry uit die publikasies van die Central Bank of Nigeria, die National Bureau of Statistics en die Food and Agricultural Organization. Data wat versamel is, is met behulp van beskrywende statistiese tegnieke ontleed. Respondente se ooreenkomsindeks (RAI) is gebruik om die veranderlikes te meet wat die prestasie van UA beïnvloed. Bevindinge het getoon dat UA $16.9 \%$ bygedra het tot vleis-/vis-/eierbehoeftes in die stad; $4.5 \%$ tot yam-/cassava-/aartappelbehoeftes; $0.58 \%$ tot groentevereistes; $0.6 \%$ tot vrugtebehoeftes, en $0.5 \%$ tot graanbehoeftes. RAl-resultate het aangedui dat swak toegang tot finansiering (0.93), beperkte grondoppervlakte (0.75) en gebrek aan verblyfsekerheid (0.44) die dominante veranderlikes was wat die swak bydrae van UA tot voedselsekerheid beïnvloed. Daar word aanbeveel dat UA in stedelike beplanning geïntegreer word en dat meer grond vir boerdery voorsien word.

Sleutelwoorde: Voedingsvereiste, stedelike landbou, stedelike beplanning, veerkragtigheid in die stad, voedselsekerheid

\section{Ho aha toropo e matlafatsang lijo ka temo ea litoropong: Temohiso ea llorin, Nigeria}

Keketseho ea baahi ba litoropong, e tsamaeang le bofuma bo ntseng bo eketseha le tlala, e bakile likhang ka bohlokoa ba temo ea litoropong ho sebetsana le liqholotso tsa khaello ea lijo litsing tsa litoropo. Sengoliloeng sena se hlahloba litlamorao tsa ts'ebetso ea meralo ea litoropo mabapi le temo ea litoropong (UA) e Ilorin, Nigeria, le hore na e kentse letsoho joang ho ntlafatseng botsitso ba toropo khaellong ea lijo. Ka ts'ebeliso ea moralo oa phuputso ea likarolo tse fapaneng, lintlha tsa mathomo le tsa bobeli li sebelisitsoe. Lenane la lipotso le hlophisitsoeng le sebelisitsoe ho fumana lintlha tsa mantlha ho lihoai tsa litoropong tse khethiloeng ka tatellano. Lintlha tsa bobeli li fumanoe likhatisong tsa Banka e Kholo ea Nigeria, Ofisi ea Naha ea Lipalopalo, le Mokhatlo oa Lijo le Temo. Lintlha tse bokelitsoeng li ile tsa hlahlojoa ho sebelisoa mekhoa e hlalosang ea lipalo. Tataiso ea Tumellano ea Baarabeli (RAI) e sebelisitsoe ho lekanya mefuta e susumetsang ts'ebetso ea UA. Liphuputso li senotse hore UA e kentse $16.9 \%$ ho litlhoko tsa nama / thapi / mahe toropong; $4.5 \%$ ho ea ho litlhoko tsa yam / cassava / litapole; $0.58 \%$ ho latela litlhoko tsa meroho; $0,6 \%$ ho ea ho litlhoko tsa litholoana, le $0.5 \%$ ho litlhoko tsa lijo-thollo. Liphetho tsa RAI li bonts'itse phihlello e mpe ea lichelete 
(0.93), sebaka se fokolang sa mobu (0.75), le khaello ea polokeho ea ho ba moahi (0.44) e le mefuta e meholo e susumetsang monehelo o mobe oa UA ho ts'ireletso ea lijo. Ho khothaletsoa hore UA e kenyeletsoe morerong oa litoropo le hore ho fanoe ka mobu o mong oa temo.

\section{INTRODUCTION}

A defining feature of Nigeria's urbanization in the $21^{\text {st }}$ century is the rapid and unrelenting urban agglomeration, with large cities of over one million people in virtually every state of the country, including the Federal Capital Territory. While urbanization is regarded as one of the indices of development, in Nigeria it is accompanied by a myriad of social, economic, physical, and environmental problems (Ola, 2011: 76-78). This has led to the questioning of spatial planning's effectiveness in managing this phenomenon. As the cities grow, there appear to be fewer solutions to its emerging challenges. More importantly, the horizontal urban expansion coupled with unabated population growth has resulted in the decline of urban carrying capacity and an increase in the vulnerability of individuals and communities in many of these cities to socioeconomic and environmental hazards (Eguaroje, Alaga, Ogbole, Omolere, Alwadood \& Kolawole, 2015: 152). Consequently, the resilience of these cities has been called to question. Urban resilience, a concept recently developed, is considered as the ability of a city to react, absorb, recover, and prepare for future shocks - economic, environmental, social, and institutional (Pike, Dawley \& Tomaney, 2010: 64). The resilient city approach to urban management seeks to promote sustainable development, wellbeing, and inclusive growth (OECD, 2010: 8). With the emergence of the concept of resilience, the city's strategy of coping with shocks transforms from passive resistance and a post-shock relief approach to active adaptation and risk assessment, better preparedness, and making use of early warning systems (Ainuddin \& Routray, 2012: 26-27; Berkes \& Ross, 2013: 8). The major social challenges of Nigerian urbanization are that urban poverty, food insecurity, and malnutrition are increasing (Metu, Okeyika \& Maduka, 2016: 6). These have led to a greater vulnerability of the country's cities to food supply shock (Fudjumdjum, Filho \& Desalegn, 2019: 1023). Thus, in recent times, food security has become a relevant issue, not only in Nigeria, but also across the globe in addressing urban resilience. Food security is a concept that has varying definitions. According to the Food and Agriculture Organization (FAO) (1996: 19), food security exists when all people, at all times, have physical and economic access to sufficient, safe, and nutritious food to meet their dietary needs and food preferences for an active and healthy life.

There has been heightened food insecurity in Nigeria, particularly in its urban centres, owing to the overdependence of cities on rural food supplies (Mohammed \& Charles, 2016: 35), along with unabated rural depopulation, the unrelenting increase in urban populations, and the current Buhari administration's stance on reducing food imports through its recent closure of land borders to forestall food entering the country illegally (WFP, 2016: 68). Available data indicate that total yearly wheat production fell from 100,000 tons in 2007 to 60,000 tons in 2018 (Nzeka, 2018: 11), whereas the country's population increased by roughly 40\% (UN, 2017: 32). A study conducted in Lagos by Roberts, Osadare and Inem (2019: 885) revealed that only $33.8 \%$ of urban households are food secure, $45.1 \%$ are food insecure without hunger, and $21.1 \%$ are food insecure with hunger. Estimates by Nzeka (2018: 24-27) suggest that $80 \%$ of the available food items in urban centres is supplied by rural areas, despite their dwindling farming population.

Various studies have shown that urban agriculture (UA) (the production of food in urban environments) contributes to cities' resilience by reducing the vulnerabilities of urban dwellers to food shock (FAO, 2016: 12; Famine and Early Warning System Network, 2016: 7). It encompasses farming in public/ semi-public spaces (schools, public rights-of-way and boulevards, and community gardens). Private property (backyards, rooftop, and balcony) also accommodates UA (Abu \& Soom, 2016: 55). Other agriculture types being conducted in the city include hydroponic, aquaculture, keeping poultry, rabbits, and bees; greenhouses; permaculture design in parks; public orchards or food forests, and agricultural parks (La Rosa, Barbarossa, Privitera \& Martinico, 2014: 296). Urban agriculture is not a new phenomenon in Nigeria (Adelekan, Olajide-Taiwo, Ayorinde, Ajayi \& Babajide, 2014: 19), but the rate of urbanization and the need to stem the tide of food insecurity have compelled governments and researchers to seek ways of improving and encouraging labour entrance into the sector.

The modern urban planning system in Nigeria appears to favour other land uses at the expense of agricultural land in the city. This can be attributed to the constraints imposed by the planning laws, especially the Land Use Act No. 29 of 1978 (Federal Republic of Nigeria, 1978: 2) and the Urban and Regional Planning Law Decree No. 88 of 1992 (FRN, 1992: 8), which became an act of parliament in 2004, with minimal alteration. For instance, both laws prohibit the cultivation of annual and perennial crops, as well as the raising of livestock in urban areas. Despite these legal constraints, UA has continued to thrive in Nigeria.

This article thus examines how land-use planning has facilitated the practice of UA in Ilorin, Kwara State, Nigeria, and how it has contributed to improving the city's resilience to food shock. Ilorin is centrally located and has unique vegetation and edaphic characteristics that provide opportunities for flourishing agricultural practices. The city has also become a major refuge for displaced people from the northern part of Nigeria following 
security challenges bedevilling that region, leading to the city's rapid population growth, with attendant food shortages and increased vulnerability to food shock.

\section{LITERATURE REVIEW}

\subsection{Climate change, urban agriculture, and city resilience}

An increase in climate changerelated extreme weather events and natural disasters, as well as chronic shocks, impact on food production, processing, and distribution along the entire food supply chain. Cities are highly vulnerable to the disruption in critical (food) supplies, and climate change exacerbates this vulnerability (FAO, 2011: 48). Urban economies suffer as rural agricultural production is adversely affected by storms, floods, shifting seasonal patterns, droughts, or water scarcity. At the same time, changing temperature and precipitation patterns affect what crops can be grown in a given locale (Nelson, Adger \& Brown, 2007: 402). Increasing food prices resulting from disruptions in food supply directly impact on consumers in urban areas, because they are almost entirely dependent on purchasing (rather than growing) their food. Vulnerable populations who are already experiencing, or at risk from food insecurity are the hardest hit (FAO, 2012: 116). Furthermore, the effects of climate change on productivity in certain rural areas can result in increased migration to cities for economic or environmental reasons, leading to the accelerated growth of slum areas.

There is a growing awareness that the combined effects of climate change, rapid urbanization, and continued population growth have the potential to undermine the resilience of cities across the globe to food shock. Increasingly, the significance of city resilience and the strong connection between resilience and the sustainability of socioecological systems is recognized (Dubbeling, Campbell, Hoekstra \& Van Veehuizen, 2009: 5). Resilience is a measure of a household, city, or nation's ability to absorb shocks and stresses (Dubbeling et al., 2009: 11). Resilient cities are characterized by increased self-reliance and their capacity to manage or bounce back from stresses or disastrous events (De Zeeuw, Van Veenhuizen \& Dubbeling, 2011: 153-154). Most importantly, UA is promoted as a more permanent feature in sustainable city planning. Greater amounts of carbon are sequestered in green growing spaces, while urban forests and green roofs help reduce urban temperatures (Newman, Beatley \& Boyer, 2008: 68).

$U A$ is conceptualized as the production of food (for example, vegetables, fruit, meat, eggs, milk, fish, and non-food items such as fuel, herbs, ornamental plants, tree seedlings, and flowers) within the urban area and its periphery, for home consumption and/or for the urban market, and related small-scale processing and marketing activities (FAO, 2018: 15-17). UA takes place on private, leased, or rented land in peri-urban areas, in backyards, on rooftops, on vacant public lands such as industrial parks, school grounds, roadsides, in prisons and other institutions as well as ponds, lakes, and rivers (Mohammed \& Charles, 2016: 38). This is regarded as a way to increase resilience by co-locating food production with consumption (Mohammed \& Charles, 2016: 43). Blay-Palmer, Santini, Dubbeling, Renting, Taguchi and Giordano (2018: 10) observed that UA is a means to shorten supply chains that are highly vulnerable to climaterelated impacts and resource scarcity because of their long global links.

The global template for development (the Sustainable Development Goals [SDGs]) emphasizes the need to "[m]ake cities and human settlements inclusive, safe, resilient, and sustainable" (SDG 11). Goal 1 advocates sustainable agriculture to help reduce poverty; goal 2 focuses on improving nutrition and reducing hunger; goal 12 asks the global community to ensure sustainable consumption and production patterns, and goal 13 requests the countries of the world to combat climate change and its impacts. These SDGs are all geared towards achieving the goal of building inclusive, safe, resilient, and sustainable cities (UN, 2015: 12). Similarly, the Paris COP21 agreement of 2015 (UN, 2016: 2-3) recognizes the fundamental priority of safeguarding food security and ending hunger and the vulnerabilities of food production systems to the impacts of climate change. Thus, building resilience in a city requires an integrated and ecosystem-based approach that considers mitigation (for example, strategies to reduce greenhouse gas emissions), adaptation (for example, reducing the vulnerability to climate change), and development (such as poverty alleviation, income generation, and food security) (World Bank, 2010: 12). It has been variously argued that, as an integral part of the urban socio-economic and ecological system, UA is a suitable strategy to address this triple challenge (Mougeot, 2000: 102; Tuts, 2011: 9). Napawan (2016: 26) emphasized the role of UA in making cities self-reliant through local food systems (local markets and food security through cooperatives of local producers).

\subsection{Integrating urban agriculture into urban planning}

The concept adopted for this study advocates for the integration of UA into urban planning. The Continuous Productive Urban Landscapes (CPULs) concept (Viljoen, Bohn \& Howe, 2005: 39) was consequently adopted to explain how this can be achieved. The CPULs concept argues for citywide networks of green and productive corridors. It was conceptualized as open landscapes productive in economical, sociological, and environmental terms, running continuously through the built urban environment, thereby connecting all kinds of existing inner-city open spaces and relating, finally, to the surrounding rural area. CPULs offer space for leisure and recreational activities, access routes, urban green lungs, and so on. But, most uniquely, they are productive by 
providing open space for UA, for the inner-urban and peri-urban growth of food (Viljoen et al., 2005: 41). CPULs include places for food production, wildlife habitat, and social activities. They connect such places by providing corridors for wildlife and human beings to travel across the city, and for airflow to cool the city (Viljoen \& Wiskerke, 2012: 44).

Building on the concept of CPULs, Solomon (2012: 133) put forward the foodscape concept, which he originally referred to as Urbaniahoeve, i.e. the city as a farmyard. Foodscape describes a physical landscape, in which horticultural knowledge, cultural practice, food-system infrastructure, and a real food-producing biotope are co-located (Solomon, 2012: 135). The central idea of the concept is that it is possible to introduce edible landscapes into public and private spaces in such a way that they restore the health of human beings and other organisms that engage with them. The maintenance of such landscapes largely involves harvesting the produce. As observed by Viljoen and Howe (2012: 280), CPULs advocate for the integration of people, their living environments, and food. The central claim of CPULs is that urban food systems play an integral role in sustainable urban systems and need to be integrated with urban ecological, cultural, and economic systems. The concept's relevance to this study is that it proposes the integration of green space with a wide range of ecosystem services that include but are not confined to the provision of food. It also provides a way to consider the city as a whole, while identifying places to make changes in that whole, which has parallels with resilience-building methods.

\subsection{Assessing Nigeria's food security}

The Global Food Security Index (GFSI), published in 2018, indicates that Nigeria's food security performance was poor. The country's score deteriorated by 1.1 points across the three core pillars (availability, access, and utilization) of food security to 38 points compared with the previous year, which is well below the average of 58.4 points of the 113 countries considered across the globe, ranking Nigeria in $94^{\text {th }}$ position. Nigeria ranks 101 in affordability; 100 in availability, and 77 in quality and safety. Consequently, Nigeria's overall performance in the GFSI for 2018 was rated "Weak", even as its nutritional standards and volatility of agriculture production were "Very Good" (Economist Intelligence Unit, 2018: 31-33). A report published by the United Nations Office for the Coordination of Humanitarian Affairs (UNOCHA) shows increased food insecurity in the Boko Haram insurgents' enclaves of Borno, Adamawa, and Yobe states between 1 June and 31 August 2019 (UNOCHA, 2019: 2). According to the report, the total number of people facing food insecurity in these states rose to 3 million from 2.7 million (UNOCHA, 2019: 8).

In 2016, the Nigerian government estimated in its Agricultural Promotion Policy (2016-2020) that there were supply gaps in 13 key crops and activities. For instance, out of 6.3 million tonnes of rice demanded, Nigeria was able to supply only 2.3 million tonnes, less than half of what could make rice affordable in the country going by its definitions. Demand for wheat was 4.7 million tonnes, but Nigeria could only supply 0.06 million tonnes, representing $1.3 \%$ of the total demand, while out of 2.7 million tonnes of fish demanded, only 0.8 million tonnes (29.6\%) were supplied (FMARD, 2016: 32). A similar trend was observed for other consumables such as yam, tomatoes, cocoa, cotton, sorghum, milk, chicken, soya beans, maize, and palm oil. The gap between supply and demand is an indication that, with Nigeria's $3.2 \%$ annual population growth rate (NBS, 2017: 6), the country's ability to produce enough food to meet the needs of its rapidly growing population is under serious pressure.
The Nigerian food Consumer Price Index (CPI) published by the National Bureau of Statistics gives insight into the affordability of food items in Nigeria. Food CPI increased by $81 \%$ from May 2015 to July 2019, while the Naira lost $56.6 \%$ of its value from N196/\$ to N306.9/\$ within the same period (NBS, 2019: 9; CBN, 2020: 14). These statistics indicate that the Nigerians' food purchasing power and income have weakened over time, thereby undermining their capacity to afford the food items as they used to. Furthermore, the World Poverty Clock, a web platform designed to provide real-time poverty estimates, shows that roughly $47.7 \%$ of Nigerians cannot afford $\$ 59.6$ in a month vis-à-vis $\$ 83.5$ required to buy a food basket in 2016 (Kharas, 2017: 6-8). Therefore, Nigeria does not meet any of the components that make a country food secure: food availability, access, utilization, and stability, as outlined by the FAO.

\section{THE STUDY AREA}

The city of Ilorin $\left(8,30^{\circ} \mathrm{N} ; 4,35 \mathrm{O} \mathrm{E}\right)$ is the seventh-largest city in Nigeria, with a 2019 projected population of 814,192 (National Bureau of Statistics, 2019: 6). It is the capital of Kwara State. Ilorin's climate is characterized by wet and dry seasons: the wet season's (March to November) annual precipitation ranges from $1000 \mathrm{~mm}$ to $1500 \mathrm{~mm}$ (Fabiyi \& Ashaolu, 2015: 17). The mean daily temperature ranges from $25^{\circ} \mathrm{C}$ in January to $27.5^{\circ} \mathrm{C}$ in May. Ilorin has Guinea savannah vegetation with riparian woodland along the bank of the Asa River, which flows from the northern end of the city southwards (World Atlas, 2019: 1).

Ilorin has a fertile sandy-loam soil type, which favours particular species of trees and grasses such as Acacia spp, Terminalia spp, Afzelia Africana, Parkia spp, and Vitellaria paradoxa (shea butter) (Olaoye \& Oloruntoyin, 2014: 3-5). The city is well watered by the various tributaries of the Niger River which traverse its valleys, between low hills (Afolabi, Olutomilola \& Ishaki, 
2018: 4). Collectively, these features provide an environment suitable for farming, hunting, and animal husbandry and perhaps explain why various groups of people and occupational activities have migrated to and settled in the area over time.

Kwara State is strategically located at the geographical and cultural confluence of the North and South, bounded in the south by the Oyo and Osun States, in the north by the Niger State, toward the east by the Kogi State and toward the west by the Benin Republic (Figure 1). llorin is $300 \mathrm{~km}$ from Lagos and the coastline, $160 \mathrm{~km}$ from Ibadan, Africa's largest indigenous city, and $300 \mathrm{~km}$ from the Federal Capital, Abuja (Aderamo, 2007). Ilorin was developed as an administrative centre for the Kwara State, but both economic and social activities have greatly influenced its growth in recent times. A good road network links llorin with many other major cities.

The choice of llorin was informed by the city's regional (central) location, sharing boundaries with the North-West and South-West geopolitical zones of the country as well as its unique vegetation and edaphic characteristics that provide opportunities for flourishing agricultural practices. Consequent upon the security challenges bedevilling the entire northern part of Nigeria and its attendant mass exodus of displaced people from the region, llorin, with its unique location, has been a major regional centre of refuge for displaced people. This has led to the rapid growth in the city's population and the attendant food shortage and increased vulnerability to food shock (Omotesho, MuhammadLawal \& Ismaila, 2014: 359).

\section{METHODOLOGY}

This study examines how land-use planning impacts on the practice of UA in Ilorin City, Nigeria, and identifies how UA contributes to achieving the resilience of the city to food shock. A mixed-methods approach was adopted to empirically analyse the role of UA in building a resilient urban community (University of Kansas, 2016: 4). This involved the collection, analysis, and merging of both quantitative and qualitative data. Quantitative data were essentially obtained from the urban farmers sampled in the city, whereas qualitative data were the outcomes of the researcher's personal observations.

\subsection{Sampling method and size}

Ilorin is made up of three Local Government Areas (LGAs), namely llorin South, Ilorin East, and Ilorin West. Ilorin West LGA has 13 political wards, while the two other LGAs each have 12 wards (INEC, 2015: 35-38). Preliminary investigations revealed that urban agricultural practices are carried out on the fringes of these wards in all the LGAs. Consequently, three wards were purposively selected for the survey from each LGA, where the rate of agricultural practice was very

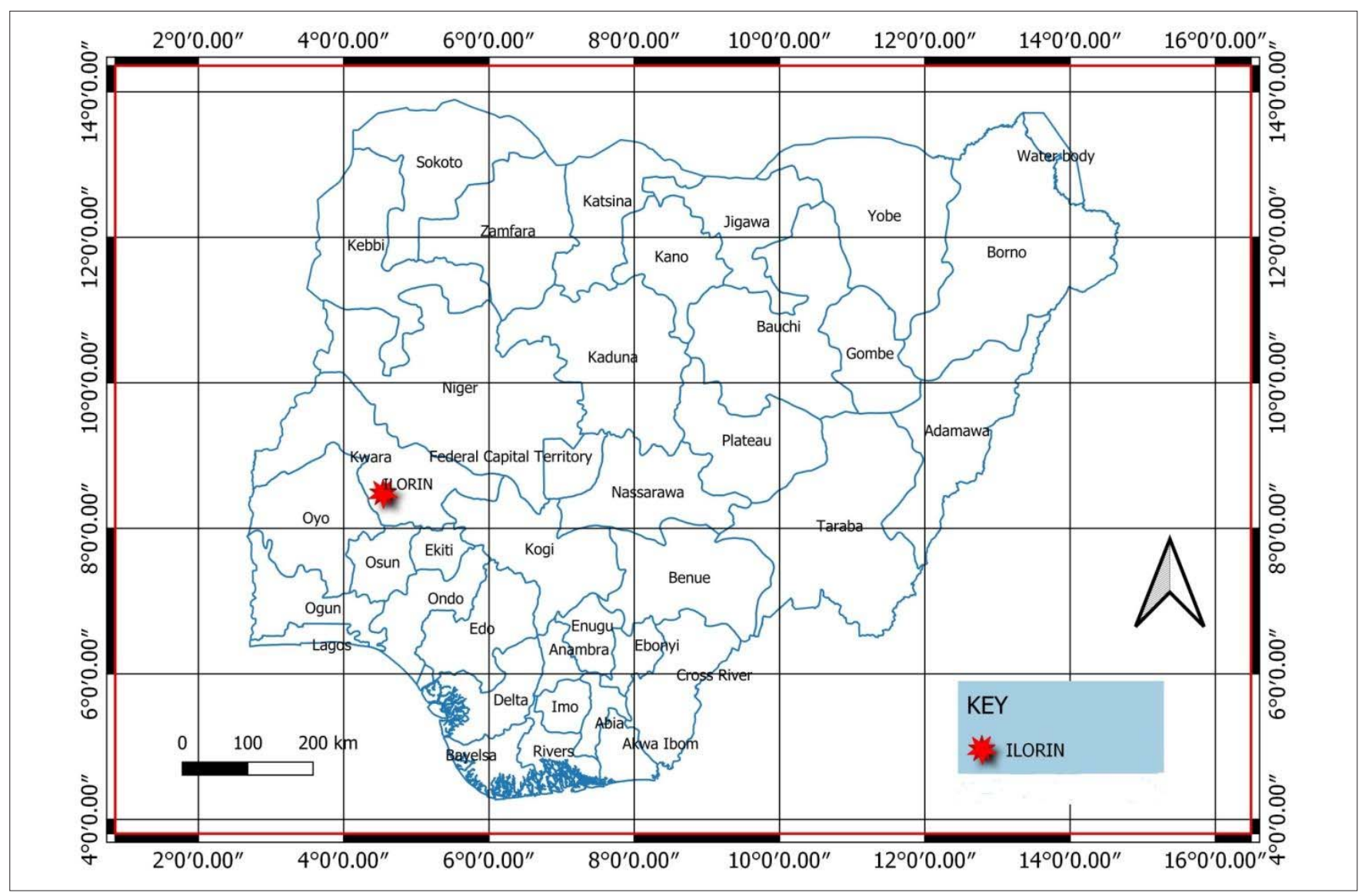

Figure 1: Ilorin within the geographical setting of Nigeria 
high (Bernard, 2000: 73-75). These are Adewole, Oko-erin, and Oloje wards for Ilorin West LGA; Akanbil, Oke-ogun, and Okaka II wards for Ilorin South LGA, and Okeoyi/okeose/ alalubosa, Zango, and Agbeyangi/ gbadamu/osin wards for llorin East.

A unique attribute of the farmers is that, while some did register with the government and with associations of urban farmers, some did not. Therefore, to have a fairly reliable figure of the farmers, the researcher, with the help of some field assistants, decided to enumerate the unregistered farmers using the snowball technique. Consequently, a total of 207 urban farmers were identified in the study area between 15 October 2019 and 20 November 2019, with Ilorin South having 52 farmers, Ilorin East having 91 , and Ilorin West having 64. The data obtained from the State Ministry of Agriculture, the National Fadama Project, and the Farmers' Association revealed that there are 398 registered farmers in the three LGAs with 157, 135, and 106 in Ilorin South, Ilorin East, and Ilorin West, respectively. Thus, a total of 605 farmers were operating in Ilorin. Fifty percent $(50 \%)$ of the farmers (i.e. 303 farmers) were randomly selected for the survey, using picking by ballot in each of the wards across the three LGAs. The breakdown is as follows: Ilorin South - 105; Ilorin East - 113, and Ilorin West -85 . The $50 \%$ samples fall within the purview of Neuman's (1994: 163) postulation that a $30 \%$ sample size for a homogeneous population of less than 1,000 is suitable for a survey at $95 \%$ confidence level, assuming $\mathrm{a}+/-5 \%$ error margin.

\subsection{Data collection}

A cross-sectional survey design was used for this study, which involved the administration of a set of structured questionnaires and observations checklist. To examine the state of urban agricultural practices, the contribution of UA to food security in Ilorin and factors influencing the percentage contribution of UA to food security, a set of pre-tested structured questionnaires was administered on the sampled 303 urban farmers in the study area between 15 and 24 July 2019 . The questionnaire included 32 tick-box and 16 open-ended questions in six parts. Part one on the socio-economic characteristics of the urban farmers included questions on gender, age, education, income, and household sizes. Part two included questions on the state of urban agricultural practices as well as questions on the mode of engagement of urban farming, years of practising urban farming, access to training in urban farming, access to agricultural extension services, size of farms, ownership of farmland, location of the farm, the distance of farmland to residences, and mode of transport to farms. Part three sought answers on crops, livestock, and other production elements and included questions on the types of livestock, crop, fruits, and mixed farming being practised. Part four covered other aspects of urban agricultural practices and included questions on agricultural mechanization, irrigation farming, use of storage facilities, and sale of farm produce. Part five focused on the contribution of $U$ to food security and included questions on average annual livestock, aquaculture, egg, crop, fruits, and tuber production by the farmers. Part six sought clarity on the factors influencing the contribution of UA to food security and included questions on access to finance, land area, security of tenure, seasonal rainfall fluctuation, theft, and knowledge of modern techniques of agriculture. The questionnaires were administered to 303 urban farmers, who were asked to tick the appropriate answers where options were supplied, while they were given the liberty to provide answers to the open-ended questions.

During the period of the survey, the spatial patterns of urban farming were observed using an observation checklist. The checklist was designed to collect information on the specific locations of the urban farms in relation to the city's morphology. All the 303 copies of the questionnaires administered were satisfactorily completed and returned for analysis.

\subsection{Data analysis and interpretation of findings}

The data collected were processed in the Statistical Package for Social Sciences (SPSS) version 21 software, where two analytical statistics were employed to summarize data and make inferences. First, univariate descriptive statistics involving frequency and percentages were used to report the socio-economic profile of urban farmers. Then, the Respondents' Agreement Index (RAI) was used to measure the factors influencing UA's contribution to food security. Six variables that could influence low productivity were identified, including limited land area, poor access to finance, seasonal fluctuation in rainfall, poor knowledge of modern farming techniques, theft of farm produce prior to harvest, and lack of tenure security. We assume that the level of agreement of the respondents would indicate the level of influence these variables have on the low contribution of UA in the study area. To calculate the RAI, the sampled farmers were instructed to rate each variable using one of the five ratings: Strongly Agree (SA) (5), Agree (A) (4), Just Agree (JA) (3), Disagree (DA) (2), and Strongly Disagree (SD) (1). The summation of weight value (SWV) for each variable was obtained through the addition of the products of responses for each rating of the variable and their respective weight values. Mathematically, this is expressed as:

$S W V=\sum_{i=1}^{5} X_{i} Y_{i} \quad$ equation (1)

Where: SWV is the summation of weight value;

$X_{i}$ is the respondents' rating of a particular variable influencing low productivity;

$Y_{i}$ is the weight value assigned to each variable.

The respondents' agreement index (RAI) for each variable is arrived at by dividing the summation of weight value by the addition of the number 
of respondents to each of the five ratings. This is expressed as:

$\mathrm{RAI}=\underline{\mathrm{SWV}}$.

equation (2)

$\sum_{i=1}^{5} P_{i}$

The information from the observation checklist was recorded on a piece of paper and reported directly in the article.

\subsection{Limitations}

The small sample size cannot be generalized across Nigeria or other countries. Therefore, the results of this study are limited to the research area. In addition, the fact that some farmers did not formally register with the Government led to the physical enumeration of farmers with the possibility of underestimation of the farmers.

\section{FINDINGS AND DISCUSSION}

\subsection{Spatial patterns of urban agriculture in Ilorin}

The various land uses that also accommodate UA in the city include residential, public/semi-public land, industrial, floodplains, and peri-urban areas. Farming takes place in many low- and medium-density residential neighbourhoods in Ilorin. This includes low-density areas such as GRA, Adewole, and Judges Quarters, and medium-density neighbourhoods such as Tanke, Oke-odo, Basin, Egbejila, Gaa Odoota, and Oloje. Public/semi-public land uses include the University of Ilorin, Kwara State Polytechnic, Kwara State College of Education, University of Ilorin Teaching Hospital, military and police barracks, Niger River Basin Development Authority, and some secondary schools. In addition, a number of industrial areas in the city have vacant lands that are being cultivated. Industrial zones such as Ajewole and Cam Wire are particularly known for UA. Floodplains are equally put to use for agricultural purposes in the city. Areas such as Asa dam, Agba dam, and the neighbourhoods along Oyan (the longest tributary of the River Niger) are witnessing intense agricultural activities. Extensive and intensive agricultural practices are also conducted in the city's peri-urban areas such as Oloje, Danialu, airport, and Oke-oyi (Figure 2).

Farming is partly encouraged in the low- and medium-density areas by the relative sizes of plots. For instance, the lot sizes in the low-density residential areas are $1,200 \mathrm{~m}^{2}$, whereas in medium-density neighbourhoods the minimum lot size is $787 \mathrm{~m}^{2}$. Public/semi-public uses attract agriculture, because most of them have less than $50 \%$ of their lot developed. Farming in these areas is mostly practised by individuals, but the management of some institutions such as the University of Ilorin and Kwara State Polytechnic equally farmed part of their land. The slow process of industrialization in Ilorin, leading to the slow development of industrial areas, appears to encourage farming there. Factory workers are mostly involved in farming in these areas, because many of them live around the areas and can easily obtain the permission of the factory management to cultivate the available open spaces around the factory buildings. The various tributaries of the Niger River within

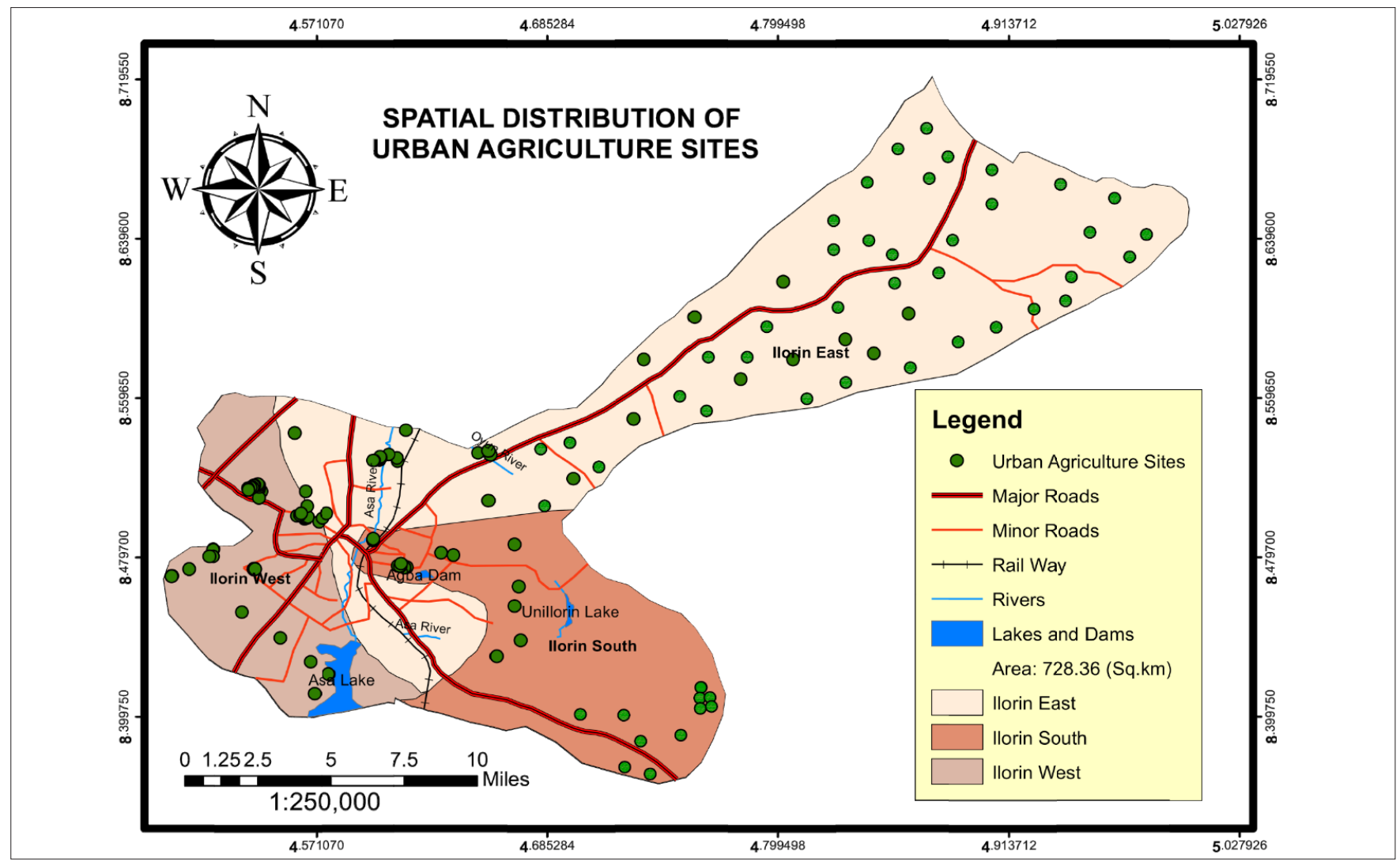

Figure 2: Spatial pattern of agricultural sites in llorin

Source: Author's field survey, 2019 
Ilorin provide suitable conditions for irrigation farming, especially during the dry season. This explains why the floodplains are attractive to a number of urban farmers in the city. The fact that these areas are not suitable for building and are usually ignored by the government and land speculators influences the practice of UA there.

\subsection{The state of urban agricultural practices in Ilorin}

A large percentage $(65.4 \%)$ of the respondents were full-time farmers, with only $18.4 \%$ having undergone special training in urban farming offered by the Kwara State Ministry of Agriculture. Approximately $39.3 \%$ of the sampled farmers had access to agricultural extension services provided by the Kwara State Government, and half (49.8\%) of them have practised UA for between 5 and 15 years (Figure 3).

The farmers had limited access to adequate space for farming, as almost half $(48.1 \%)$ of the respondents operated on a plot area of less than $540 \mathrm{~m}^{2}$. This implies that farmland per person is too small and can hardly allow large-scale production. This probably explains why many of the crop farmers were merely subsistence. Analysis of landownership among the farmers revealed a widespread of leasing $(41.2 \%)$ and owner-occupier (34.8\%). This amplifies Stone's (2016) position that lack of tenure security portends grave danger for expansion and development of UA. Most (85.0\%) of

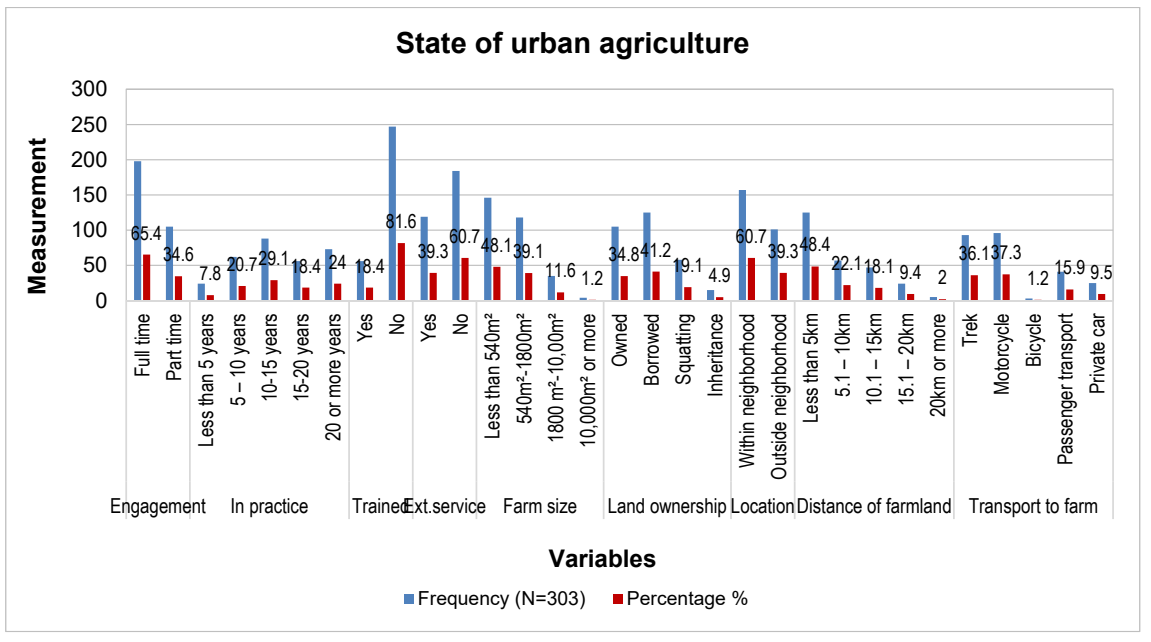

Figure 3: State of urban agriculture

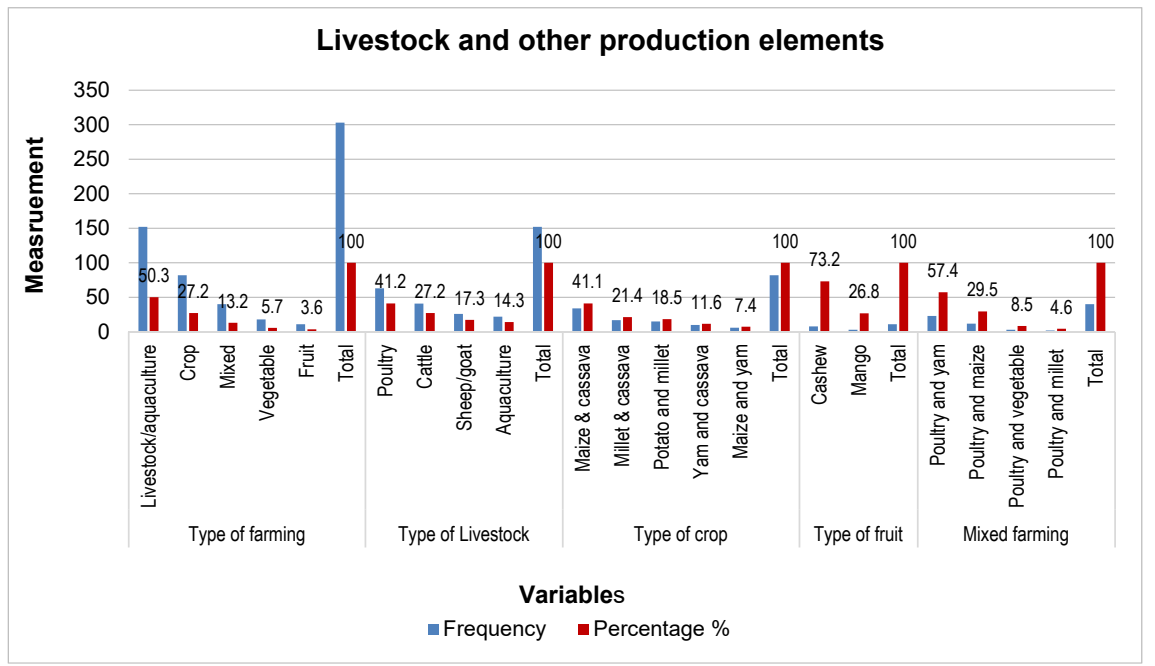

Figure 4: Livestock and other production elements

these agricultural lands were open fields located outside the residential compounds of the farmers, with $60.7 \%$ having their farms within their neighbourhoods and $39.3 \%$ having their farms outside their neighbourhoods. However, ove half $(48.4 \%)$ of the respondents travelled a distance of more than $5 \mathrm{~km}$ to their farms, and $62.7 \%$ reached their farms using motorized transport (Figure 3).

Issues discussed are very central to building a food-resilient city. It is gratifying to note that some of the variables are on the positive side. This includes the fact that many of the farmers were into full-time farming, have appreciable years of experience in farming, and had their farms within their residential neighbourhoods. These variables indicate the quality and readiness of the farmers to expand if given the opportunity. However, the basic variables that can aid the farmers' operation are on the negative side. These include farm size (which is an index of access to adequate land), training (to keep the farmers abreast of modern techniques of farming), and poor access to extension services. Thus, despite the experience and readiness of the farmers, the enabling environment is lacking. This suggests that UA as currently practised in Ilorin may be incapable of building the city's ability to withstand and cope with food shocks.

\subsection{Crops, livestock, and other production elements}

A substantial percentage (50.3\%) of the sampled farmers practised livestock farming and aquaculture; $27.2 \%$ engaged in crop farming; $13.2 \%$ practised mixed farming (i.e. both crop and livestock farming); $5.7 \%$ focused solely on vegetable farming, while $3.6 \%$ were into fruit farming (Figure 4). This confirms the assertions of earlier studies that considered UA to be largely characterized by the rearing of animals and the growing of plants (Adelekan et al., 2014: 42; RUAF, 2004: 76). 
The livestock farmers $(50.3 \%)$ focused on poultry, cattle, sheep, and goats that were the common livestock being reared, although $14.3 \%$ of the farmers focused mainly on aquaculture. The poultry farmers accounted for $41.2 \%$ of the livestock farmers, the cattle herders accounted for $27.2 \%$, while $17.3 \%$ farmed with sheep and goats. Common crops grown by the crop farmers were gains (millet and maize) and tubers (yam, cassava, and potato). All the crop farmers practised mixed cropping. Thus, of the $27.2 \%$ farmers who practised crop farming, $41.1 \%$ grew maize and cassava; $21.4 \%$ grew millet and cassava; $18.5 \%$ grew potato and millet; $11.6 \%$ grew yam and cassava, and $7.4 \%$ grew maize and yam. In addition, common fruit farms found in the area were cashew and mango. Some $73.2 \%$ and $26.8 \%$ of the fruit farmers were into cashew and mango farming, respectively. Those practising mixed farming $(13.2 \%)$ can be disaggregated as follows: poultry and yam farming (57.4\%); poultry and maize farming (29.5\%); poultry and vegetable farming $(8.5 \%)$, and poultry and millet farming (4.6\%) (Figure 4). Similar patterns of farming were reported in Ibadan (Nigeria) by Adelekan et al. (2014: 51) and in Tamale (Ghana) by Gyasi, Fosu, Kranjac-Berisavljevic, Mensah, Obeng, Yiran and Fuseini (2014: 27-28), respectively.

\subsection{Other aspects of urban agriculture}

Mechanization is an important requirement of agricultural practice. Evidence suggests that mechanization has a major impact on the level of cultivated land, agricultural productivity, demand and supply of farm labour, profitability and ultimately improving the livelihoods of farmers (FAO \& UNIDO, 2008: 179; Schmitz \& Moss, 2015: 23). There was limited use of modern machinery among the sampled farmers, as $94.7 \%$ of the farmers were not practising agricultural mechanization. Only $5.3 \%$ of the respondents who were mainly poultry farmers used modern machinery in their operation (Figure 5). It appears that the limited size of farmland among the crop farmers prevented some of them from engaging in mechanized farming.

The seasonal pattern of rainfall influenced some of the farmers $(18.7 \%)$ to engage in irrigation farming, especially during the dry season. It should be noted that all the farmers who practised irrigation farming had their farms along the river course and water dam in the city. An essential aspect of farming is having storage facilities to preserve and store excess produce against damage and destruction by adverse weather and rodents, respectively. Approximately $41.5 \%$ of the farmers had storage facilities, of whom poultry/aquaculture farmers accounted for $97.8 \%$ and crop farmers $2.2 \%$ (Figure 5). Storage facilities mostly used by the poultry farmers were crates, egg-boxes, and freezers. Aquaculture farmers used mostly refrigerators and freezers, while crop farmers used silos. The economic motive has been identified as a causative factor in labour entrance into urban agricultural practices (Lawal \& Aliu, 2012: 94; Sulaiman, Olubunmi, Balogun \& Falegbe, 2015: 67). This explains why $47 \%$ of the respondents sold a substantial part of their produce to the public, while $53 \%$ of them practised mainly subsistence farming (Figure 5).
The combination of mechanized farming, irrigation farming, and the use of storage facilities results in an abundance of food for consumption and export all year round. With these practices, only a small proportion of the population is required to feed a city/country, while their exports will boost the country's international trade. The inadequacy of these in llorin points to the fact that the city is less secure to food shocks.

\subsection{Contributions of urban agriculture to food security in Ilorin}

One of the principal foci of this work is to examine the contribution of UA to achieving food security in the city of Ilorin. Table 1 presents the quantity of livestock, fish, and egg produced annually by urban farmers in the city. Poultry products including egg constituted the highest quantity of livestock products. This may not be unconnected with the higher number of farmers operating in the poultry sector and the fact that poultry production rate is naturally the highest among the livestock animals, although it may not give the highest quantity of meat.

Table 2 presents the quantity of grains, vegetables, tubers, and fruits produced annually. A higher number of farmers focused on the production of maize rather than millet in the

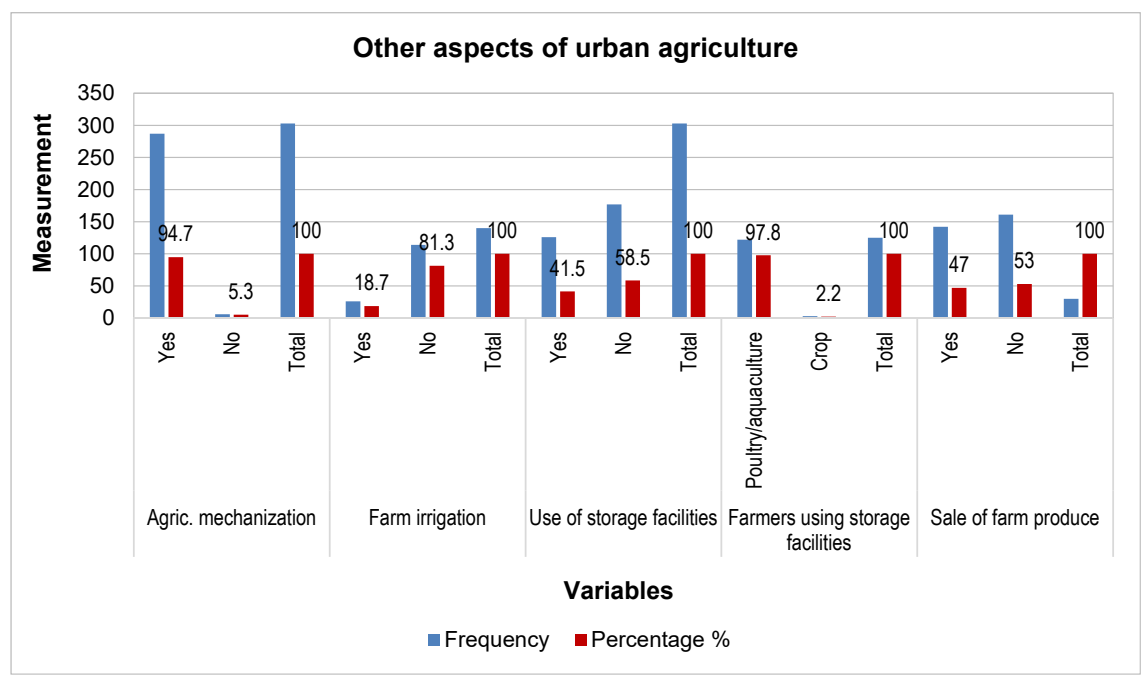

Figure 5: Other aspects of urban agriculture 
grain subsector, while cassava was produced more than other tuber crops in the tuber subsector. In addition, more farmers engaged in cashew production than in mango in the fruits subsector. The higher economic value and ready market for cashew compared to mango in the area appear to be responsible for this trend. There are a number of cashew processing factories in the city that purchased the cashew nuts for processing and export to other countries in the world.

As shown in Table 3, UA accounted for $16.9 \%$ of the meat, fish, and egg requirements of city dwellers. This is followed by $4.5 \%$ contribution to tuber requirements of the people, while fruits, vegetables, and grains accounted for $0.6 \%, 0.5 \%$, and

Table 1: Urban livestock produce in Ilorin

\begin{tabular}{|l|c|c|c|c|}
\hline Livestock & $\begin{array}{c}\text { Average no. per } \\
\text { farmer }\end{array}$ & $\begin{array}{c}\text { Annual rate of } \\
\text { increase/farmer/yr }\end{array}$ & No. of farmers & $\begin{array}{c}\text { Total production/ } \\
\mathbf{y r}(\mathbf{k g})\end{array}$ \\
\hline Poultry & 100 & 1,000 & 126 & 126,000 \\
\hline Goats/sheep & 20 & 30 & 66 & 1,980 \\
\hline Cattle & 20 & 20 & 113 & 2,260 \\
\hline Fish & 200 & 1,000 & 44 & 44,000 \\
\hline Egg & $60 /$ day & 21,900 & 126 & $2,759,400$ \\
\hline Total & & & & $\mathbf{2 , 9 3 3 , 6 4 0}$ \\
\hline
\end{tabular}

Table 2: $\quad$ Urban crop and fruit produce in Ilorin

\begin{tabular}{|l|c|c|c|c|}
\hline \multicolumn{1}{|c|}{ Crop types } & $\begin{array}{c}\text { Frequency of } \\
\text { growth per year }\end{array}$ & $\begin{array}{c}\text { Average annual } \\
\text { yield per farmer } \\
\mathbf{( k g )}\end{array}$ & No. of farmers & Production(kg) \\
\hline Maize & 2 & 600 & 92 & 55,200 \\
\hline Millet & 2 & 350 & 39 & 13,650 \\
\hline Vegetable & 3 & 5,390 & 41 & 220,990 \\
\hline Yam & 2 & 1,800 & 76 & 136,800 \\
\hline Potato & 1 & 1,200 & 30 & 36,000 \\
\hline Cassava & 1 & 4,000 & 122 & 488,000 \\
\hline Cashew & 1 & 12,000 & 16 & 192,000 \\
\hline Mango & 1 & 15,500 & 6 & 90,000 \\
\hline
\end{tabular}

Table 3: Nutritional requirements of urban dwellers and \% contribution by UA in Ilorin

\begin{tabular}{|l|c|c|c|c|c|}
\hline \multicolumn{1}{|c|}{ Food Item } & DNR (kg) & MNR (kg) & ANRP (kg) & ASUA (kg) & \% SUA \\
\hline Meat/Fish/Egg & 47,500 & $1,425,000$ & $17,337,500$ & $2,933,640$ & 16.92 \\
\hline Maize/Millet & 39,900 & 119,7000 & $14,563,50$ & 68,850 & 0.47 \\
\hline Vegetable & 104,500 & 313,5000 & $38,142,50$ & 220,990 & 0.58 \\
\hline Fruits & 123,500 & $3,705,000$ & $45,077,500$ & 282,000 & 0.63 \\
\hline Yam/Cassava/Potato & 39,900 & $1,197,000$ & $14,563,500$ & 660,800 & 4.54 \\
\hline
\end{tabular}

Table 4: Respondents' Agreement Index (RAI)

\begin{tabular}{|c|c|c|c|c|c|c|c|c|c|}
\hline \multirow[t]{2}{*}{$S / N$} & \multirow{2}{*}{$\begin{array}{l}\text { Factors influencing } \\
\text { low contribution }\end{array}$} & \multicolumn{5}{|c|}{$\begin{array}{c}\text { (5) - Strongly agree }-(1) \text { Strongly } \\
\text { disagree }(\mathrm{N}=303)\end{array}$} & \multirow[t]{2}{*}{ SWV } & \multirow[t]{2}{*}{ RAI(MS) } & \multirow[t]{2}{*}{ MD(RAI) } \\
\hline & & 5 & 4 & 3 & 2 & 1 & & & \\
\hline 1 & $\begin{array}{l}\text { Poor access to } \\
\text { finance }\end{array}$ & 163 & 57 & 33 & 0 & 0 & 1142 & 4.51 & 0.93 \\
\hline 2 & Limited land area & 110 & 94 & 32 & 0 & 0 & 1022 & 4.33 & 0.75 \\
\hline 3 & $\begin{array}{l}\text { Lack of tenure } \\
\text { security }\end{array}$ & 132 & 90 & 51 & 38 & 0 & 1249 & 4.02 & 0.44 \\
\hline 4 & $\begin{array}{l}\text { Seasonal fluctuation } \\
\text { in rainfall }\end{array}$ & 51 & 92 & 76 & 100 & 21 & 1072 & 3.15 & -0.43 \\
\hline 5 & Theft & 68 & 74 & 31 & 87 & 78 & 981 & 2.90 & -0.68 \\
\hline \multirow[t]{2}{*}{6} & $\begin{array}{l}\text { Knowledge of modern } \\
\text { techniques }\end{array}$ & 22 & 37 & 29 & 83 & 41 & 552 & 2.60 & -0.98 \\
\hline & $\begin{array}{l}\text { Average RAI(MS) } \\
\text { (composite score) }\end{array}$ & & & & & & & 3.58 & \\
\hline
\end{tabular}

$0.4 \%$, respectively, of the people's requirements. The study revealed a very low contribution of UA in meeting the nutritional needs of city dwellers. This lends credence to the earlier observations that all the indices that can position UA as the most important factor for building the resilience of Ilorin to food shock are simply lacking.

Note: DNRP - Daily Nutritional Requirement per Person;

ANRP - Annual Nutritional

Requirement/Person; ASUA - Amount Supplied by Urban Agriculture; \% SUA - Percentage Supplied by Urban Agriculture.

The nutritional requirements were calculated based on the FAO/ WHO recommendations of DNRP as follows: Meat $(0.05 \mathrm{~kg})$; Maize/ Millet $(0.042 \mathrm{~kg})$; Vegetable $(0.11 \mathrm{~kg})$; Fruits $(0.13 \mathrm{~kg})$; Yam/Cassava/Potato $(0.042 \mathrm{~kg})$. Note that the calculation was based on the 2020 projected population of Ilorin which is 950,000 .

\subsection{Factors accounting for low contribution of urban agriculture to food security in Ilorin}

While a number of studies have identified low contributions of UA to food security especially in developing countries (WFP, 2016: 71-74; Metu et al., 2016: 8-9; Sulaiman et al., 2015: 66), specific factors influencing this phenomenon were examined in relation to the study area and the result is presented in Table 4. RAI is a technique of analysis that rates factors against a scale, in order to assess the significance of each factor. The scale is then transformed into RAI for each factor, in order to determine the ranking of the different factors. RAl is computed using the formula presented in section 4.3.

As shown in Table 4, the highest RAI was 4.51 and the lowest was 2.60. Therefore, the deviations around the mean of the highest and lowest RAI were 0.93 and -0.98 , respectively. The variables with positive deviations around the mean (i.e. RAI) were the variables considered by the sampled farmers to be the leading causes of the low contribution of UA to food 
requirements in the study area.

These variables were poor access to finance (0.93); limited land area (0.75), and lack of tenure security (0.44). The variables with negative deviations around the mean were those considered not to be the dominant/principal factors influencing the low contribution of UA to food security. The farmers showed a lower level of agreement on them. Such variables include poor knowledge of modern techniques of agriculture $(-0.98)$; theft $(-0.68)$, and seasonal fluctuation in rainfall $(-0.43)$. The average RAI of 3.58 indicates that all respondents, on average, 'agree' that all 6 factors influence the low contribution of UA to food security.

Evidence from the literature indicates that spatial planning decisions in Ilorin, like in any city in Nigeria, have been guided largely by political and economic considerations. This has resulted in haphazard development and stimulated over-building, thus leading to inadequate land being available for agriculture. The recent attempt by the Kwara State Government to prepare a master plan for the city is a step in the right direction, but an imminent failure awaits the project, because the Chairman and many members of the planning committee were geographers, while physical planners were not accorded vantage role in the scheme of things. This study revealed that the less coordinated approach to urban planning in the city has given rise to inadequate green space for $U A$, despite the interest of some urban dwellers in this sector. The lack of adequate space has partly led to the minimal contribution of UA to the nutritional needs of the residents.

\section{CONCLUSION AND RECOMMENDATIONS}

As in other countries, urban planning practice is shaped by the quality of available legislation, the response of physical planners to emerging urban problems, and the willingness of the political leaders to oblige the physical planners. Results show that the major constraint to efficient urban agricultural practice in Nigeria is the Planning Law Decree 88 of 1992 and the Land Use Act No. 29 of 1978 , because they have ensured that the planning response to urban issues is very slow, lacks proper coordination, and is not always in tune with the modern approach required to address most of these problems. Since the emergence of Ilorin as the state capital in 1975, no master plan has been prepared to guide the city's development. This study thus concludes that, presently, Ilorin does not have the resilience to food shocks. The implication of this is that the city may not be able to meet the five relevant SDGs highlighted earlier. This portends grave dangers for the socio-economic stability of not only the city but also of the entire State, thereby undermining the government's efforts to achieve a peaceful and egalitarian society. What is to be done? The following strategies may be adopted.

- $\quad$ There is a need to integrate UA into the planning and design of the city. UA is not usually factored into city planning as a result of the false notion that real agriculture takes place in rural areas only. But this study has shown that real agriculture can take place in urban areas, if the land is made available for the purpose. Ilorin has a particularly vast expanse of undeveloped, arable land. Thus, the current attempt by the Kwara State Government to prepare a master plan for the city of Ilorin presents a good opportunity to achieve this purpose. Ample greenbelt zones should be provided in the plan to cater to agricultural purposes and to control urban development activities in the city. To effectively position greenbelt zones in the city design, Viljoen et al.'s (2005: 39) Continuous Productive Urban Landscapes concept comes in handy.

- The services of agricultural extension workers in offering technical advice and training for farmers should be intensified and restructured to achieve maximum coverage of the farmers in the city. The training should focus on modern agricultural techniques such as mechanized farming, soil-erosion control, and bio-intensive farming practices to enhance soil fertility, check soil degradation, and make optimal use of urban land made available for this purpose.

- A boost in urban agricultural productivity and output is achievable if farmers have easy access to modern farm machinery such as tractors, harvesters, sprayers, and so on, and farm inputs such as pesticides, improved seedlings, organic fertilizers, and so on. To ensure this, farmers' adequate access to finance must be guaranteed. Despite some federal governmentowned agricultural financing organizations (such as the Nigeria Agricultural Development Bank) being present in the country, these establishments usually require stringent conditions for farmers to access loans. These effectively inhibit many indigent farmers to access these loans. Thus, the financial establishments need to evolve realistic conditions of accessing loans and work with the Kwara State's Ministry of Agriculture and Farmers' Association in Ilorin to ensure adequate coverage of loan facilities and recovery arrangements.

- Theft of agricultural products on the farms should be squarely addressed by the government. Because the Nigerian security agencies are overstretched as a result of current security challenges in the country, the establishment of an outfit to be probably named 'Farm Security Corps' by the Kwara State Government may be required. The existence of such an outfit will undoubtedly reduce the menace, thereby encouraging farmers to produce more and more farmers to join the urban agricultural sector. 
- Rooftop gardening has been found to contribute significantly to food security. A substantial quantity of food in Kathmandu Metropolitan Municipality (Nepal) comes from rooftop gardening (Dubbeling, Veenhuizen \& Halliday, 2019: 37). This initiative can be adopted in Ilorin, and by extension other parts of Nigeria. Considering the nature of roofing in the city, the existing building code should be reviewed to accommodate agriculturepermissive roofs. Residents should also be sensitized to the significance of rooftop gardening.

- To achieve purposeful and sustainable UA, the State Government through the State Planning Bureau and Agriculture Ministry must develop a comprehensive municipal UA and food security policy and programme that should facilitate the integration of UA into climate-change adaptation and disaster-management strategies of the city.

\section{REFERENCES}

ABU, G. \& SOOM, A. 2016. Analysis of factors affecting food security in rural and urban farming households of Benue State, Nigeria. International Journal of Food and Agricultural Economics, 4(1), pp. 55-68.

ADELEKAN, I., OLAJIDE-TAIWO, L., AYORINDE, A., AJAYI, D. \& BABAJIDE, S. 2014. Building urban resilience: Assessing urban and peri-urban agriculture in Ibadan, Nigeria. Nairobi, Kenya: United Nations Environment Programme (UNEP).

ADERAMO, A.J. 2007. Transport and socio-economic development in Kwara State, Nigeria. The Nigerian Journal of Economic and Social Studies, 49(1), pp. 27-44.

AFOLABI, O.O., OLUTOMILOLA, O.O. \& ISHAKI, J.D. 2018. Assessment of groundwater system characteristics in Ilorin Metropolis, South-Western Nigeria. American Journal of Water Science and Engineering, 4(1), pp. 1-8. https://doi.org/10.11648/j. ajwse.20180401.11
AINUDDIN, S. \& ROUTRAY, J.M. 2012. Community resilience framework for an earthquake prone area in Baluchistan. International Journal of Disaster Risk Reduction 2(1), pp. 25-36. https://doi. org/10.1016/j.ijdrr.2012.07.003

BERKES, F. \& ROSS, H. 2013. Community resilience: Toward an integrated approach. Society and Natural Resources, 26(1), pp. 5-20. https://doi.org/10.1080/08941920.2012 .736605

BERNARD, H.R. 2000. Social research methods: Qualitative and quantities approaches. Thousand Oaks, CA: Sage Publications Inc.

BLAY-PALMER, A., SANTINI, G., DUBBELING, M., RENTING, H., TAGUCHI, M. \& GIORDANO, T. 2018. Validating the city region food system approach: Enacting inclusive, transformational city region food systems. Sustainability, 10(5), pp. 8-12. https://doi.org/10.3390/su10051680

CBN (CENTRAL BANK OF NIGERIA). 2020. Exchange rate by currency -23/6/2020. [Online]. Available at: <https//www.cbn.gov.ng/rates/ exchangeratebycurrency/currencytype> [Accessed: 24 June 2020].

DE ZEEUW, H., VAN VEENHUIZEN, R. \& DUBBELING, M. 2011. The role of urban agriculture in building resilient cities in developing countries. The Journal of Agricultural Science, 149(1), pp. 153-163. https://doi.org/10.1017/ S0021859610001279

DUBBELING, M., CAMPBELL, M., HOEKSTRA, F. \& VAN VEEHUIZEN, R. 2009. Building resilient cities. Urban Agriculture Magazine, vol. 22, pp. 3-11.

DUBBELING, M., VEENHUIZEN, R. \& HALLIDAY, J. 2019. Urban agriculture as a climate change and disaster risk reduction strategy. The Journal of Field Action, Special Issue 20, pp. 32-39.

ECONOMIST INTELLIGENCE UNIT.

2018. Global Food Security Index 2018: Building resilience in the face of rising food-security risks. London: The Economist Intelligence Unit.

EGUAROJE, O., ALAGA, T., OGBOLE, J., OMOLERE, S., ALWADOOD,

J. \& KOLAWOLE, I. 2015. Flood vulnerability assessment of Ibadan City, Oyo State, Nigeria, World Environment, vol. 5, pp. 149-159.
FABIYI, I.P. \& ASHAOLU, E.D. 2015.

Spatio-temporal pattern of rainfall distribution over llorin metropolis, Nigeria. Scientia Africana, 14(2), pp. 16-21.

\section{FAMINE AND EARLY WARNING}

NETWORK. 2016. Nigeria food security outlook June 2016 to January 2017. [Online]. Available at: <https://fews.net/ sites/default/files/documents/reports/ Nigeria> [Accessed: 21 April 2020].

FAO (FOOD AND AGRICULTURE ORGANIZATION). 1996. Urban agriculture: An oxymoron? The state of food and agriculture 1996. Rome: FAO.

FAO (FOOD AND AGRICULTURE ORGANIZATION). 2011. Food, agriculture and cities: Challenges of food and nutrition security, agriculture and ecosystem management in an urbanizing world. Rome: FAO.

FAO (FOOD AND AGRICULTURE ORGANIZATION). 2012. Growing greener cities in Africa. First status report on urban and peri-urban horticulture in Africa. Rome: FAO.

FAO (FOOD AND AGRICULTURE ORGANIZATION). 2018. Strengthening resilient food and agriculture systems - Implementing the Sendai Framework for DRR in the agriculture sector in Asia and the Pacific. [Online]. Available at: <https//www.fao.org> [Accessed: 9 June 2020].

FAO (FOOD AND AGRICULTURE ORGANIZATION) AND UNIDO (UNITED NATIONS INDUSTRIAL DEVELOPMENT ORGANIZATION). 2008. Agricultural mechanization in Africa: Time for action: Planning investment for enhanced agricultural productivity. Rome: FAO.

FMARD (FEDERAL MINISTRY OF AGRICULTURE AND RURAL DEVELOPMENT). 2016. The Agriculture Promotion Policy (20162020): Building on the successes of the ATA, closing key gaps - Policy and strategy document. Abuja:FMARD.

FRN (FEDERAL REPUBLIC OF NIGERIA). 1978. Land Use Act. Lagos, Nigeria: FRN.

FRN (FEDERAL REPUBLIC OF NIGERIA). 1992. Nigerian Urban and Regional Planning Decree No. 88. Supplement of Official Gazette Extraordinary No. 75; 31 December 1992. Lagos, Nigeria: FRN. 
FUDJUMDJUM, H., FILHO, W.L. \& DESALEGN, Y.A. 2019. Assessment of barriers to food security in North-Eastern Nigeria. In: Filho, W.H. (Ed.). Handbook of climate change resilience. Cham, Switzerland: Springer International Publishing, pp. 1019-1033. https://doi. org/10.1007/978-3-319-93336-8_99

\section{GLOBAL FOOD SECURITY}

INDEX. 2019. Rankings and trends. [Online]. Available at: <https://www. foodsecurityindex.eiu.com/Index> [Accessed: 21 May 2020].

GYASI, E.A., FOSU, M., KRANJACBERISAVLJEVIC, G., MENSAH, A., OBENG, F., YIRAN, G. \& FUSEINI, I. 2014. Building urban resilience: Assessing urban and peri-urban agriculture in Tamale, Ghana. Nairobi, Kenya: United Nations Environment Programme (UNEP).

\section{INEC (INDEPENDENT NATIONAL} ELECTORAL COMMISSION). 2015. Directory of polling units Kwara State. Revised, January 2015. Ilorin, Nigeria: INEC.

KHARAS, H. 2017. Making everyone count: A clock to track poverty in real time. Brookings Institution Global Economy and Development Paper No. 5 , pp. 6-8.

\section{LA ROSA, D., BARBAROSSA, L., PRIVITERA, R. \& MARTINICO, F.} 2014. Agriculture and the city: A method for sustainable planning of new forms of agriculture in urban contexts. Land Use Policy, 41(1), pp. 290-303. https://doi. org/10.1016/j.landusepol.2014.06.014

LAWAL, M.O. \& ALIU, I.R. 2012. Operational pattern and contribution of urban farming in an emerging megacity: Evidence from Lagos, Nigeria. In: Szymańska, D. \& Biegańska, J. (Eds). Bulletin of Geography. SocioEconomic Series, No. 17. Torun: Nicolaus Copernicus University Press, pp. 87-97. https://doi.org/10.2478/ v10089-012-0009-1

MARTIN, W. \& MARTIN, L. 2018. How to grow a city: Cultivating an urban agriculture action plan through concept mapping. Agriculture \& Food Security, 7(33), pp. 1-9. https://doi.org/10.1186/ s40066-018-0186-0
METU, A., OKEYIKA, K. \& MADUKA, O. 2016. Achieving sustainable food security in Nigeria: Challenges and way forward. In: Proceedings of the $3^{\text {rd }}$ International Conference on African Development Issues, 9-11 May, Otta, Nigeria, pp. 143-148.

MOHAMMED, N.C. \& CHARLES, P. 2016. Political economy analysis of small scale farmers and food security in Nigeria. European Journal of Business and Social Science, 5(4), pp. 35-49.

MOUGEOT, P. 2000. Urban agriculture: Definition, presence, potentials and risks. In: Bakker, N., Dubbeling, M., Gündel, S., Sabel-Koschella, U. \& De Zeeuw, H. (Eds). Growing cities, growing food: Urban agriculture on the policy agenda. A reader on urban agriculture. Feldafing: DSE/ETC.

NAPAWAN, N.C. 2016. Complexity in urban agriculture: The role of landscape typologies in promoting urban agriculture's growth. Journal of Urbanism, 9(1), pp. 19-38. https://doi.or g/10.1080/17549175.2014.950317

NBS (NATIONAL BUREAU OF STATISTICS). 2017. Demographic Statistics Bulletin. [Online]. Available at: <https//www.nigerianstat.gov.ng. [Accessed: 5 January 2020].

NBS (NATIONAL BUREAU OF STATISTICS). 2019. Consumer Price Index Feb. 2019. [Online]. Available at: <https//www.nigerianstat.gov.ng> [Accessed: 5 November 2020].

NELSON, D.R., ADGER, W.N. \& BROWN, K. 2007. Adaptation to environmental change: Contributions of a resilience framework. Annual Review of Environment and Resources, 32(1), pp. 395-419. https://doi.org/10.1146/ annurev.energy.32.051807.090348

NEUMAN, W.L. 1994. Social research methods: Qualitative and quantitative approaches. $2^{\text {nd }}$ edition. Boston, MA: Adyn and Bacon.

NEWMAN, P., BEATLEY, T. \& BOYER, H. 2008. Resilient cities: Responding to peak oil and climate change. New York: Island Press.

NZEKA, U. 2018. Nigeria grain and feed annual report 2018. Report prepared for USAID Foreign Agricultural Service, Global Agricultural Information Network. Washington, DC: USAID
OECD (ORGANIZATION FOR ECONOMIC CO-OPERATION AND DEVELOPMENT). 2010. Innovative financing mechanisms for the water sector. Paris: OECD Publishing.

OLA, A.B. 2011. Fiscal federalism and urban development in Nigeria. International Journal of Development Studies, 6(3), pp. 76-83.

OLAOYE, J.O. \& OLORUNTOYIN, Z.T. 2014. Vegetation characteristic of ecological zones of Kwara State, Nigeria, and responses to different land clearing options. Paper presented at the International Conference of Agricultural Engineering, AgEng, 6-10 July, Zurich, Switzerland.

OMOTESHO, K.F., MUHAMMADLAWAL, A. \& ISMAILA, D.E. 2014. Assessment of hired labour use and food security among rural farming households in Kwara State, Nigeria. Journal of Agricultural Sciences, 59(3), pp. 353-361. https://doi.org/10.2298/ JAS14033530

PIKE, A., DAWLEY, S. \& TOMANEY, J. 2010. Resilience, adaptation and adaptability. Cambridge Journal of Regions Economy Society, 3(1), pp. 59-70. https://doi.org/10.1093/cjres/ rsq001

ROBERTS, A.A., OSADARE, J.O. \& INEM, V.A. 2019. Hunger in the midst of plenty: A survey of household food security among urban families in Lagos State, Nigeria. Journal of Public Health Africa, 10(1), pp. 885. https://doi. org/10.4081/jphia.2019.885

RUAF. 2004. Women feeding cities - Gender mainstreaming. In: Urban Food Production and Food Security. Proceedings of the Workshop jointly organised by ETC-RUAF and CGIARUrban Harvest in collaboration with IWMI-Ghana, 20-23 September, Accra, Ghana, pp. 76-81.

SCHMITZ, A. \& MOSS, C.B. 2015. Mechanized agriculture: Machine adoption, farm size, and labor displacement. AgBioForum, 18(3), pp. 278-296.

SOLOMON, D. 2012. Cultured and landscaped urban agriculture. After Zero, 8(1), pp. 132-137.

STONE, C.A. 2016. The urban farmer: Growing food for profit on leased and borrowed land. New York: New Society Publishers. 
SULAIMAN, A.Y., OLUBUNMI, L., BALOGUN, O. \& FALEGBE, E. 2015. Effect of urban household farming on food security status in Ibadan metropolis, Oyo State, Nigeria. Journal of Agricultural Sciences, 60(1), pp. 61-75. https://doi.org/10.2298/ JAS1501061Y

TUTS, N. 2011. Cities as key actors to act on food, water and energy security in the context of climate change. In:

Dubbeling, M. (Ed.) Urban Agriculture Magazine 27: Urban Agriculture as a Climate Change and Disaster Risk Reduction Strategy. Leusden, The Netherlands: RUAF Foundation, pp. 9-17.

UN (UNITED NATIONS). 2015. Transforming our world: The 2030 Agenda for Sustainable Development. United Nations - Sustainable Development knowledge platform. [Online]. Available at: <https://www. sustainabledevelopment.un.org/ post2015/transforming our world> [Accessed: 8 May 2020].

UN (UNITED NATIONS). 2016.

Secretary-General's remarks to the press at COP22. [Online]. Available at: <https://www.un.org.> [Accessed: 18 June 2020].

UN (UNITED NATIONS). 2017. World population prospects: The 2017 revision. United Nations Department of Economic and Social Affairs, Population Division. [Online]. Available at: <https://www.esa.un.org. > [Accessed: 21 April 2020].

UNIVERSITY OF KANSAS. 2016.

Conducting research to influence policy. [Online]. Available at: <https://www.ctb. ku.edu> [Accessed: 7 January 2020].

UNOCHA (UNITED NATIONS OFFICE FOR THE COORDINATION OF HUMANITARIAN AFFAIRS). 2019. North-east Nigeria: Borno, Adamawa and Yobe states Humanitarian Dashboard (July 2019). Published 12 tember 2019. [Online]. Available at: <https://www.unocha.org> [Accessed: 21 April 2020]

VILJOEN, A. \& HOWE, J. 2012.

Continuous productive urban landscapes. Oxford, UK: Routledge. https://doi.org/10.4324/9780080454528

VILJOEN, A. \& WISKERKE, J. 2012. Sustainable food planning: Evolving theory and practice. Wageninen, The Netherlands: Wageninen Academic Publishers. https://doi. org/10.3920/978-90-8686-826-1
VILJOEN, A., BOHN, K. \& HOWE, J. 2005. Continuous productive urban landscapes: Designing urban agriculture for sustainable cities. Oxford, UK: Architectural Press.

WFP (WORLD FOOD PROGRAM). 2016. Nigeria situation report no. 01, 13 September 2016. [Online]. Available at: <https://www.reliefweb.int/report/ nigeria/wfp-nigeria-situation-report-0113-september-2016> [Accessed: 26 May 2020].

WORLD ATLAS. 2019. Where is Ilorin, Nigeria? [Online]. Available at: $<$ https://www.worldatlas.com/af/ng/kw/ where-is-ilorin.html.ank> [Accessed: 25 November 2019].

WORLD BANK. 2010. World

Development Report - Development and climate change. [Online]. Available at: <https//www.worldbank.org.> [Accessed: 11 June 2020]. 